\title{
Co-Chemotherapeutic Effect of Ageratum conyzoides L. Chloroform Fraction and 5-Fluorouracil on Hela Cell Line
}

\author{
Rifki Febriansah*, Titi Komalasari
}

\section{Rifki Febriansah*, Titi} Komalasari

School of Pharmacy, Faculty of Medicine and Health Sciences, Universitas

Muhammadiyah Yogyakarta, Yogyakarta, INDONESIA.

\section{Correspondence}

Rifki Febriansah

School of Pharmacy, Faculty of Medicine and Health Sciences, Universitas

Muhammadiyah Yogyakarta, Yogyakarta, INDONESIA.

E-mail: rifki.febriansah@umy.ac.id

History

- Submission Date: 05-02-2019;

- Review completed: 18-05-2019;

- Accepted Date: 25-07-2019.

DOI : 10.5530/pj.2019.11.146

Article Available online

http://www.phcogj.com/v11/i5

Copyright

(c) 2019 Phcogj.Com. This is an openaccess article distributed under the terms of the Creative Commons Attribution 4.0 International license.

\begin{abstract}
Objective: This study was to determine the co-chemotherapeutic effect of the chloroform fraction of bandotan (Ageratum conyzoides L.) (CFB) and its combination with 5-Fluorouracil (5-FU) by in vitro and in silico assay. Methods: Ethanolic extract of bandotan were fractionated with chloroform. Thin Layer Chromatography (TLC) used to identify active compound and in vitro study with MTT Assay to determine the viability of HeLa cells after extract treatment. Molecular docking used Autodock Vina for in silico study to visualize molecular interaction and affinity between nobiletin and 5-FU with Bcl-XL protein. Results: The result of TLC for CFB showed the Rf value of 0.75 , it has the similar value with quersetin standard and indicated that CFB contains flavonoid compound. The molecular docking had $\Delta \mathrm{G}$ for nobiletin and 5-FU were -8.0 and $-4.7 \mathrm{kcal} / \mathrm{mol}$, respectively. This result showed that the affinity of nobiletin with $\mathrm{Bcl}-\mathrm{XL}$ protein higher than 5-FU. Single cytotoxic assay of CFB and 5-FU showed the $\mathrm{IC}_{50}$ value of 30 $\mu \mathrm{g} / \mathrm{ml}$ and $45 \mu \mathrm{g} / \mathrm{ml}$, respectively. Combination assay of CFB and 5-FU showed the $\mathrm{Cl}$ value of 0.36 , meaning the presence of synergistic effects. Conclusions: CFB has a positive effect to inhibit viability of HeLa cervical cancer cells and potential to develop as co-chemotherapy agent with 5-FU.
\end{abstract}

Key words: Ageratum conyzoides L., Cytotoxic assay, Molecular docking, Bcl-XL protein Nobiletin.

\section{INTRODUCTION}

Cervical cancer is the fourth largest cancer in women and ranks seventh of all types of cancer in all populations in the world. Each year an estimated 528,000 new cases with death rates of up to 266,000 cases by $2012 .{ }^{1}$ Side effects of chemotherapy such as fatigue, hair loss, nausea, vomiting, diarrhea, or dry mouth are quite high. In patients with cervical cancer, there are various abnormal proteins resulting in changes of cell behavior, increased proliferation and differentiation of cells and decreased ability of cell to apoptosis. One of the proteins that play a role in anti apoptosis is Bcl-XL. Normally, these proteins work to maintain the balance of differentiation and apoptosis, but in cancer patients this protein expression was increased so that the process of cell apoptosis was inhibited and cells become immortal. ${ }^{2}$ To overcome the abnormalities of these cells, then treatment with chemotherapy, radiation or surgery is still option for cancer patients. ${ }^{3}$ Different types of existing treatments produce many harmful side effects during treatment. Therefore, to improve the efficacy of cancer treatment as well as minimize side effects can be done through the development of co-chemotherapy agents from natural materials. Development of medicines from natural ingredients is possible, some chemotherapy drugs of cervical cancer patients also come from wild plants, such as vinblastine and vincristine from tapak dara. ${ }^{4}$ One of the potential natural ingredients as a cochemotherapy agent is bandotan herb.

Previous research has shown the effectiveness of bandotan as an antioxidant, antibacterial, anxiolytic ${ }^{5}$ antidiabetic ${ }^{6}$ and cytotoxic agents based on in vivo study. ${ }^{7}$ Nobiletin flavonoid compounds in bandotan are thought to play a role in anticancer activity so that it can be combined with cancer drugs and is expected to work synergistically as cochemotherapy. ${ }^{8}$ The aim of this research is to know the effectivity of combination between CFB and 5-FU as co-chemotherapy in HeLa cervical cancer cells based on in vitro study using MTT assay and molecular docking on Bcl-XL protein based in silico study.

\section{MATERIAL AND METHOD}

\section{Plant determination}

Bandotan (Ageratum conyzoides L.) plants were obtained from Bantul, Yogyakarta and was determined in Faculty of Pharmacy, Universitas Gadjah Mada, Yogyakarta.

\section{Extraction and fractination}

Preparation of extracts using maceration technique. ${ }^{9}$ The extract was carried out using maceration method with $70 \%$ ethanol solvent in ratio of 1:10 for 5 days and re-maceration for 2 days. The extracts were then fractionated with chloroform solvent with extract and chloroform ratio of $1: 1$. The chloroform fraction was concentrated using rotary evaporator at $60^{\circ} \mathrm{C}$ and $100 \mathrm{rpm}$.

\section{Single cytotoxic test by MTT assay}

The solution of chloroform fraction of $10^{5} \mu \mathrm{g} / \mathrm{ml}$ was prepared and several series concentrations were

Cite this article: Febriansah R, Komalasari T. Co-Chemotherapeutic Effect of Ageratum conyzoides L. Chloroform Fraction and 5-Fluorouracil on Hela Cell Line. Pharmacog J. 2019;11(5):913-8. 
made. Cells with a density of $1 \times 10^{4}$ cells/well are distributed into 96 well plate and incubated for $48 \mathrm{~h}$ to adapt and stick to the bottom of the well. Then, medium was taken, washed with PBS and then added 100 $\mu \mathrm{L}$ culture medium containing only $0.2 \%$ DMSO (control) or single test sample (CFB and 5-FU) incubated for $48 \mathrm{~h}$. At the end of the incubation, culture medium containing the sample was removed, washed with $100 \mu \mathrm{L}$ PBS. Then into each well was added $100 \mu \mathrm{L}$ culture medium containing $5 \mathrm{mg} / \mathrm{ml} \mathrm{MTT}$, incubating again for $4 \mathrm{~h}$ at $37^{\circ} \mathrm{C}$. Living cells react with MTT to form a purple formazan crystals. After $4 \mathrm{~h}$, the medium containing MTT was removed, washed PBS and then added an SDS stopper solution in $0.1 \% \mathrm{HCl} 200 \mu \mathrm{L}$ to dissolve the formazan crystals. Rocked over a shaker for 10 min then read with an ELISA reader at a $595 \mathrm{~nm}$ wavelength. The absorption value is converted into live cell \% then calculated $\mathrm{IC}_{50}$ value with linear regression equation.

\section{Combination cytotoxic test by MTT assay}

Cells with a density of $5 \times 10^{3}$ cells $/ 100 \mu$ in RPMI medium were distributed into 96 well plates of $100 \mu \mathrm{l}$ each and left 3 empty wells for media control then incubated for $2 \mathrm{~h}$ to recover and return to normal after harvesting the cells. After the normal cells returned, a series of chloroform and 5-fluorouracil concentration was prepared with $1 / 2 \mathrm{IC}_{50}$, $3 / 8 \mathrm{IC}_{50}, 1 / 4 \mathrm{IC}_{50}$ and $1 / 8 \mathrm{IC}_{50}$ concentrations.

Well the plate containing the cell was taken from the incubator then the medium was discarded and the cell washed with $100 \mu \mathrm{l}$ PBS, then the PBS was removed and the liquid was drained with a tissue. For the combined treatment group, $50 \mu \mathrm{l}$ was added per series of chloroform fraction concentration into the well and replicated 3 times then $50 \mu \mathrm{l}$ of 5 -fluorouracil concentration series each. For a single group, $50 \mu \mathrm{l}$ was added for each series of concentration of chloroform or 5-fluorouracil fraction into the well and replicated 3 times then $50 \mu \mathrm{l}$ of RPMI each added. For the control of the cell was added $100 \mu \mathrm{l}$ of RPMI into the wells that already contain cells and replicated 9 times. For media controls added $100 \mu \mathrm{l}$ of RPMI into an empty well and replicated 3 times. All treatments are incubated in the $\mathrm{CO}_{2}$ incubator.

A $5 \mathrm{mg} / \mathrm{ml} \mathrm{MTT} \mathrm{stock} \mathrm{was} \mathrm{prepared} \mathrm{by} \mathrm{weighing} 50 \mathrm{mg}$ of MTT powder and dissolved in $10 \mathrm{ml}$ PBS. The MTT reagent for treatment $(0.5 \mathrm{mg} / \mathrm{ml})$ was prepared by taking $1 \mathrm{ml}$ of MTT $5 \mathrm{mg} / \mathrm{ml}$ stock and diluted with RPMI up to $10 \mathrm{ml}$. Cell media was removed and re-washed with PBS and then added $100 \mu \mathrm{l}$ MTT $0.5 \mathrm{mg} / \mathrm{ml}$ to each well including media control. The cells were incubated for $2-4 \mathrm{~h}$ in the incubator until crystals of purple formazan crystals were formed and the crystals were observed under an inverted microscope. When the formazan was clearly formed, a 10\% SDS stopper in $0.1 \mathrm{~N} \mathrm{HCL}$ was added. Plates that have been given SDS are wrapped with paper or aluminum foil and recirculated at room temperature overnight. The next day, the absorbance can be read with ELISA reader at $\lambda 595 \mathrm{~nm}$ then calculated the percentage of the living cell and CI (Combination Index) of the treatment.

\section{Molecular docking with Autodock Vina}

Molecular docking begins by downloading all required applications and test active compounds (Nobiletin and 5-Fluorouracil are downloaded at Pubchem.com) and target proteins (Bcl-XL and Native ligand are downloaded in Protein Data Bank (GDP) (www.rcsb.org) with ID1YG GDP).

Further protein target preparation (PDB ID of Bcl-XL is 1YSG) with DS Visualizer application. The Bcl-XL protein is stored with the file name 1YSG with the DS visualizer app being converted into .pdb format with the Open Babel app. Each compound to be docked were given 9 conformations with different RMSD values. A valid docking protocol is a docking protocol that generates conformation with a RMSD value less than $2 \AA$ then the conformation was docked until an energy affinity or score docking was obtained. Visualization using DS Visualizer for Define Ligand and Ligand Interaction so that it will be seen clearly bonding position of active compound test and protein Bcl-XL then labeled amino acids that bind to the active compound. Compounds that have good inhibitory potential against the Bcl-XL protein are compounds with the lowest affinity or the lowest score docking.

\section{RESULTS}

\section{Plant determination}

Based on the results of plant determination, it was determined that the samples were Ageratum conyzoides L. from Asteraceae family (Figure $1)$.

\section{Extraction dan fractination}

The maceration and re-maceration extracts were combined to obtain a liquid extract of $8.82 \mathrm{~L}$. The extracts produced from the maceration process then fractionated using chloroform. A total of 1 $\mathrm{L}$ chloroform fraction and $1 \mathrm{~L}$ of extract were evaporated with rotary vacuum evaporator. This process result $3.275 \mathrm{~g}$ Chloroform Fraction of Bandotan (CFB) and $22.213 \mathrm{~g}$ of viscous ethanolic extract were obtained. Chloroform fraction of bandotan and ethanol extract yielded of $3.7 \%$ and $16.33 \%$, respectively.

\section{Single cytotoxic test by MTT assay}

A single cytotoxic test to find out $\mathrm{IC}_{50}$ values in $\mathrm{CFB}$ and 5 -FU. The HeLa cell line were treated by CFB and 5-FU to know the potency of the compound in order to inhibit the cell development.

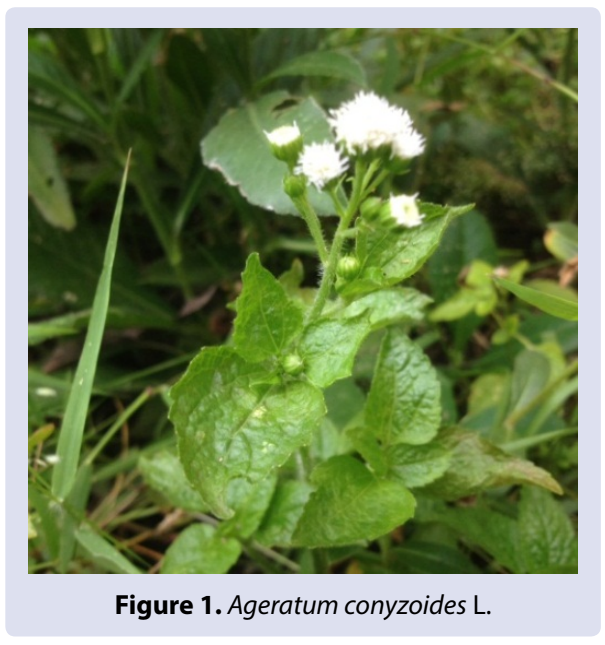

Table 1. The viability of HeLa cells with CFB treatment.

\begin{tabular}{|c|c|c|c|}
\hline $\begin{array}{c}\text { Concentration } \\
(\mu \mathrm{g} / \mathrm{ml})\end{array}$ & $\begin{array}{c}\text { Average } \\
\text { Absorbance }\end{array}$ & Viability Cell (\%) & $\begin{array}{l}\text { Standard } \\
\text { Deviation }\end{array}$ \\
\hline 1.5625 & 0,873 & 94,45 & 10,91 \\
\hline 3,125 & 0,841 & 90,66 & 8,04 \\
\hline 6,25 & 0,799 & 85,70 & 3,95 \\
\hline 12,5 & 0,732 & 77,89 & 3,76 \\
\hline 25 & 0,554 & 56,99 & 3,36 \\
\hline 50 & 0,148 & 9,41 & 0,53 \\
\hline \multirow{2}{*}{ Absorbance Average } & Cell control & 0,912 & \\
\hline & Medium & 0,067 & \\
\hline Equality & & $\begin{array}{c}\mathrm{y}=-1.732 \mathrm{x}+97.602 \\
\mathrm{R}^{2}=0,9967 \\
\mathrm{IC}_{50}=\mathbf{2 7 , 4 8} \boldsymbol{\mu g} / \mathbf{m l}\end{array}$ & \\
\hline
\end{tabular}


The $\mathrm{IC}_{50}$ value of CFB in HeLa cell line was $27,48 \mu \mathrm{g} / \mathrm{ml}$ (Table 1) and by $5-\mathrm{FU}$ was $41,46 \mu \mathrm{g} / \mathrm{ml}$ (Table 2). Based on the diagram informed that the \% cell viability of HeLa cell line was decreased with increasing of the extract and 5-FU concentration (Figures 2 and 3).

\section{Combination cytotoxic test by MTT assay}

Combination test was done to know the effect of extract in combination with 5-FU to inhibit the HeLa cell line development and progression compared with single treatment. The increasing of the concentration of the compound could decreased the amount of living cells and change the HeLa cell morphological (Figure 4).

The viability of HeLa cells was decreased when treated the combination of CFB and 5-FU in higher concentration (Table 3). The best $\mathrm{CI}$ value form the combination of $\mathrm{CFB}$ and 5-FU was obtained in the lowest concentration with CI value was 0.36 (sinergystic) and in higher combination showed the CI value was additive and antagonist (CI value $>0.8)$ (Table 4$)$.

\section{Molecular docking with Autodock Vina}

Molecular docking was done to know the interaction between compound and protein target. The lower of the docking score showed the stronger interaction between the compound and protein target.

\section{Table 2. The viability of HeLa cells with 5-FU treatment.}

\begin{tabular}{cccc}
\hline $\begin{array}{c}\text { Concentration } \\
(\mu \mathrm{g} / \mathrm{ml})\end{array}$ & $\begin{array}{c}\text { Absorbance } \\
\text { Average }\end{array}$ & Cell Viability (\%) & $\begin{array}{c}\text { Standard } \\
\text { Deviation }\end{array}$ \\
\hline 1.69 & 0.778 & 83.32 & 7.19 \\
3.38 & 0.750 & 80.00 & 7.57 \\
9.76 & 0.755 & 80.59 & 2.38 \\
19.53 & 0.629 & 65.78 & 10.35 \\
39.06 & 0.475 & 47.82 & 2.01 \\
78.125 & 0.256 & 22.08 & 1.32 \\
Absorbance & Cell control & 0,912 & \\
Average & Medium & 0,067 \\
& \multicolumn{3}{c}{$\mathrm{y}^{-0.8183 \mathrm{x}+83.932}$} \\
Equality & $\mathrm{R}^{2}=0.983$ \\
& $\mathbf{I C}_{50}=\mathbf{4 1 , 4 6} \boldsymbol{\mu g} / \mathbf{m l}$ \\
\hline
\end{tabular}

Table 3. The \% viability of HeLa cells in combination treatment of CFB and 5-FU.

\begin{tabular}{ccccccc}
\hline & \multicolumn{6}{c}{ 5-FU $(\mu \mathrm{g} / \mathrm{ml})$} \\
\hline & & 0 & 5.625 & 11.25 & 16.875 & 22.5 \\
& 0 & 100 & 63.20 & 64.63 & 63.78 & 63.71 \\
$\mathrm{CFB}(\mu \mathrm{g} / \mathrm{ml})$ & 3.75 & 81.79 & 49.92 & 53.45 & 61.37 & 62.15 \\
& 7.5 & 79.17 & 60.82 & 59.09 & 59.87 & 60.11 \\
& 11.25 & 73.97 & 57.76 & 56.85 & 58.41 & 57.12 \\
& 15 & 71.12 & 55.79 & 54.26 & 48.35 & 54.23 \\
\hline
\end{tabular}

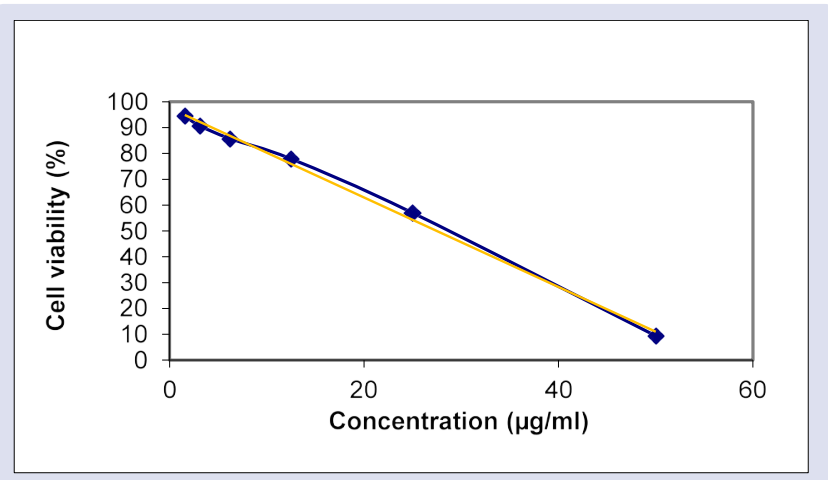

Figure 2. Single cytotoxic CFB curve effect on HeLa cells line.

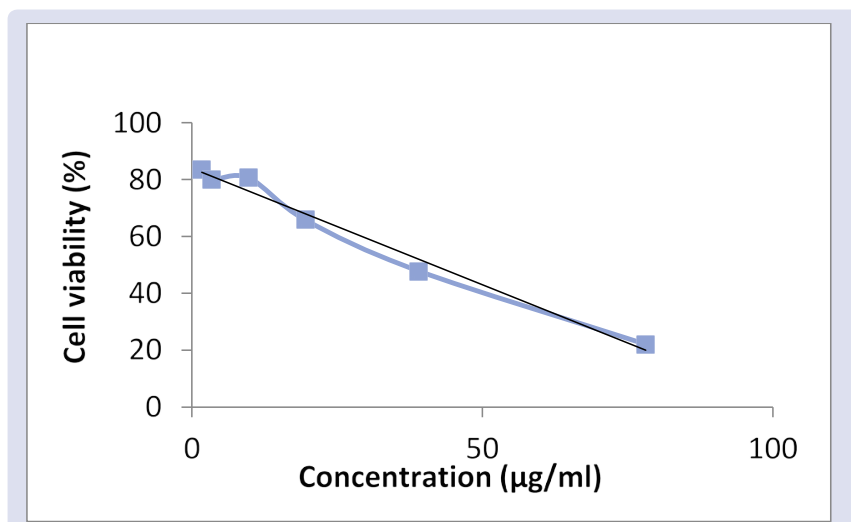

Figure 3. Single 5-FU cytotoxic effects curve on HeLa cells line.

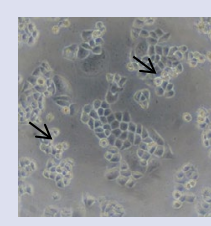

(a)

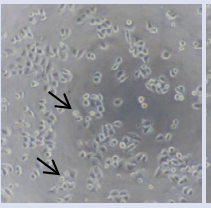

(e)

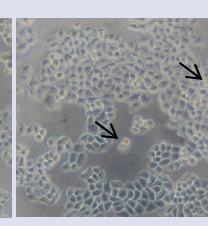

(b)

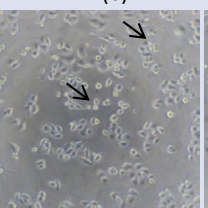

(f)

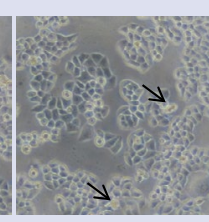

(c)

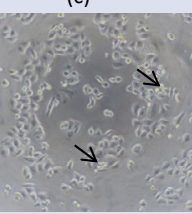

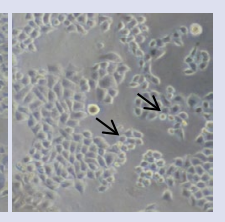

(d)

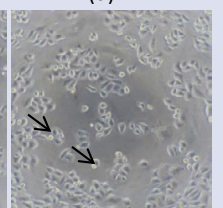

(h)
Figure 4. An overview of HeLa cell morphology under an inverted microscope (2) after being treated with a single sample (a) CFB 3.75 $\mu \mathrm{g} / \mathrm{ml}$ (b) CFB $7.5 \mu \mathrm{g} / \mathrm{ml}$ (c) CFB $11.25 \mu \mathrm{g} / \mathrm{ml}$ (d) CFB $15 \mu \mathrm{g} / \mathrm{ml}$ (e) $5-F U$ $5,625 \mu \mathrm{g} / \mathrm{ml}$ (f) 5 -FU $11.25 \mu \mathrm{g} / \mathrm{ml}$ (g) 5-FU $16.875 \mu \mathrm{g} / \mathrm{ml}$ (h) 5-FU $22.5 \mu \mathrm{g} /$ $\mathrm{ml}$; 100x magnification; The black arrow $(\rightarrow)$ shows cells undergoing morphological changes.

\section{Table 4. Combination Index (CI) value of combination CFB and 5-FU.}

\begin{tabular}{cccccc}
\hline & & & $5-F U$ & & \\
& 0.00 & 5.625 & 11.25 & 16.875 & 22.5 \\
CFB & 3.75 & 0.36 & 0.68 & 1.51 & 2.02 \\
& 7.5 & 0.97 & 1.23 & 1.66 & 2.05 \\
& 11.25 & 1.08 & 1.33 & 1.78 & 1.96 \\
& 15 & 1.20 & 1.37 & 1.17 & 1.86
\end{tabular}

The nobiletin compound resulted $-8.0 \mathrm{kcal} / \mathrm{mol}$ and become the lowest interaction rather than other compound (eupalestin and 5-FU) in the experiment, as well with the native ligands (Tables 5 and 6).

\section{DISCUSSIONS}

The results of a single cytotoxic test show that CFB has a high potential in inhibiting viability of cervical cancer cells HeLa with $\mathrm{IC}_{50} 27.48 \mu \mathrm{g} /$ $\mathrm{ml}$, lower than $\mathrm{IC}_{50}$ of its comparative 5-FU cancer drug with $\mathrm{IC}_{50} 41.46$ $\mu \mathrm{g} / \mathrm{ml}$. However, both of these have included high potency compounds as chemopreventive agents with $\mathrm{IC}_{50}$ values $<100 \mu \mathrm{g} / \mathrm{ml}$.

Previous studies with 24 -h incubation periods showed that $\mathrm{IC}_{50} 5-\mathrm{FU}$ value of HeLa cells was $1.97 \mu \mathrm{g} / \mathrm{ml}$, so the possibility of HeLa cells used was still sensitive to $5-\mathrm{FU}^{10}$ whereas according to the other study, ${ }^{11}$ the $\mathrm{IC}_{50} 5$-FU value was $71.50 \mu \mathrm{g} / \mathrm{ml}$. In this research, incubation for $48 \mathrm{~h}$, so that $\mathrm{IC}_{50} 5$-FU value is lower than previous research with $41,46 \mu \mathrm{g}$ / ml. Higher $\mathrm{IC}_{50}$ values with $71.50 \mu \mathrm{g} / \mathrm{ml}$, suggesting HeLa cells are beginning to be resistant to chemotherapy drugs because E5 expression derived from HPV degrades 533 protein. ${ }^{12}$ 
Table 5. Molecular docking result in Bcl-XL protein.

\begin{tabular}{lccc}
\multicolumn{1}{c}{ Compounds } & Conformation & RMSD Value & $\begin{array}{c}\text { Docking Score } \\
\text { (kcal/mol) }\end{array}$ \\
\hline Nobiletin & 2 & 1,128 & $-8,0$ \\
Eupalestin & 5 & 1,374 & $-7,0$ \\
5-FU & 2 & 1,508 & $-4,7$ \\
Native Ligand 4FC & 5 & 1,761 & $-6,9$ \\
Native Ligand TN1 & 2 & 1,002 & $-6,2$ \\
\hline
\end{tabular}

\section{Table 6. Docking visualization.}

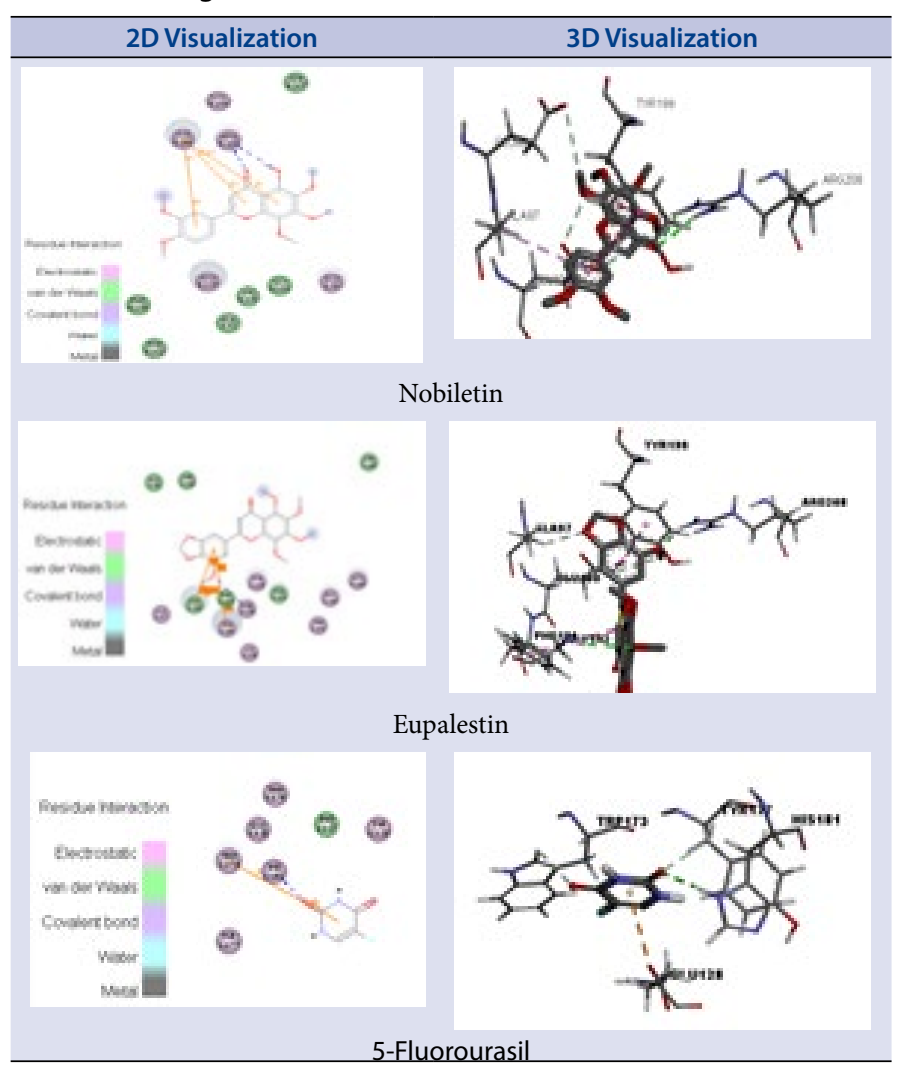

Based on the result of single cytotoxic test in $\mathrm{CFB}$ and 5-FU, a combination test of $\mathrm{CFB}$ and $5-\mathrm{FU}$ was performed to provide a synergistic cytotoxic effect even better with a combined lower dose of 5-FU than a single 5-FU. So that the side effects of chemotherapy drugs could be lowered along with decreasing dose. Combination test at below of single $\mathrm{IC}_{50}$ concentration, ie $1 / 2,3 / 8,1 / 4$ and $1 / 8 \mathrm{IC}_{50} \mathrm{CFB}$ and 5 -FU. Cytotoxic test results showed the best cell viability in a combination of $15 \mu \mathrm{g} / \mathrm{ml} \mathrm{CFB}\left(1 / 2 \mathrm{IC}_{50}\right)$ and $16,578 \mu \mathrm{g} / \mathrm{ml} 5-\mathrm{FU}\left(3 / 8 \mathrm{IC}_{50}\right)$ with $48.35 \%$ viable of cell and $3.75 \mu \mathrm{g} / \mathrm{ml} \mathrm{CFB}\left(1 / 8 \mathrm{IC}_{50}\right)$ and $5.625 \mu \mathrm{g} / \mathrm{ml}$ 5 -FU $\left(1 / 8 \mathrm{IC}_{50}\right)$ with $49.92 \%$ viable of cell while the other combination results in cell viability $>50 \%$. Combined test show that the increase concentration of combination was not proportional to the number of cell viability (Figure 5).

The CFB with the chemical content of flavonoid compounds and their derivatives induces cell apoptosis by increasing Bax protein expression and decreases $\mathrm{Bcl}-2$ protein expression in $\mathrm{A} 549^{13}$ lung cancer cells or combined MCF-7 breast cancer cells with doxorubicin through increased expression of p53 protein. ${ }^{14}$ So after the treatment of cell shape become damaged (not irregular) that indicates the cell is doing apoptosis. The 5-FU affects the cell's DNA so that mutations occur and eventually the cells will necrosis (Figure 6).

One of molecular mechanism for inhibiting the development of cancer cells was cell apoptosis involving Bcl-2 family proteins. Validation results with Autodock Vina indicated that protocol docking of nobiletin, eupalestin, 5-FU and native ligand of $\mathrm{Bcl}-\mathrm{xl}$ ( $4 \mathrm{TH}$ and $\mathrm{TH} 1$ ) in conformation 2 and the $4 \mathrm{FC}$ original ligand in conformation 5 were validated with RMSD $<2 \AA$. RMSD was the value of deviation between ligand conformation and the comparison. ${ }^{15}$ The results of molecular docking showed that docking score of nobiletin $(-0,8 \mathrm{kcal} / \mathrm{mol})$ and eupalestin $(-7.0 \mathrm{kcal} / \mathrm{mol})$ were more negative than 5-FU (-4.7 kcal / mol) and Bcl-xl native ligand (docking score $4 \mathrm{FC}$ and TH1 -6.9 and $-6.2 \mathrm{kcal} / \mathrm{mol}$, respectively). This result proved nobiletin and eupalestin bonding more stable with Bcl-xl than 5-FU and native ligand (Figure 7). ${ }^{16}$

Based on previous studies, nobiletin has been shown to have antitumor activity through antiproliferation mechanisms, apoptotic induction, cell cycle deregulation, ${ }^{17}$ antiangiogenesis, ${ }^{18}$ antiinflammatory and anticarcinogenic, ${ }^{19}$ and other pharmacological activities through in vitro and in vivo assay. ${ }^{20} \mathrm{As}$ for the results of this study, Nobiletin has the potential to have anticancer activity through the mechanism of apoptosis involving the protein $\mathrm{Bcl}-\mathrm{xl}$ in silico.

Cell apoptosis occurs due to the destruction of DNA or cell components through caspase activation. Caspase activation of intrinsic pathways mediated by the $\mathrm{Bcl}-2$ family protein as an apoptotic regulator and outer mitochondrial membrane strength. The Bcl-2 protein family consists of pro-apoptotic proteins (Bax and $\mathrm{Bak}$ ) and anti-apoptosis ( $\mathrm{Bcl}-\mathrm{xl}, \mathrm{Bcl}-2)$. The process of apoptosis can be triggered by a response to stress, damage to cells or infected cells, cell hemostasis and the cause of apoptosis such as anti-cancer agents. $^{21}$

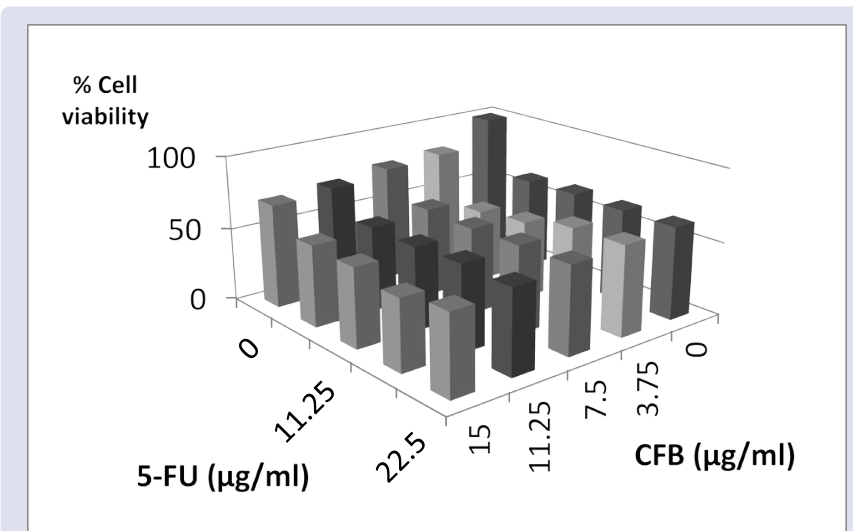

Figure 5. Graphic of HeLa cell viability in CFB and 5-FU single and combination treatment at $1 / 2,3 / 8,1 / 4$ and $1 / 8 I_{50}$ levels.

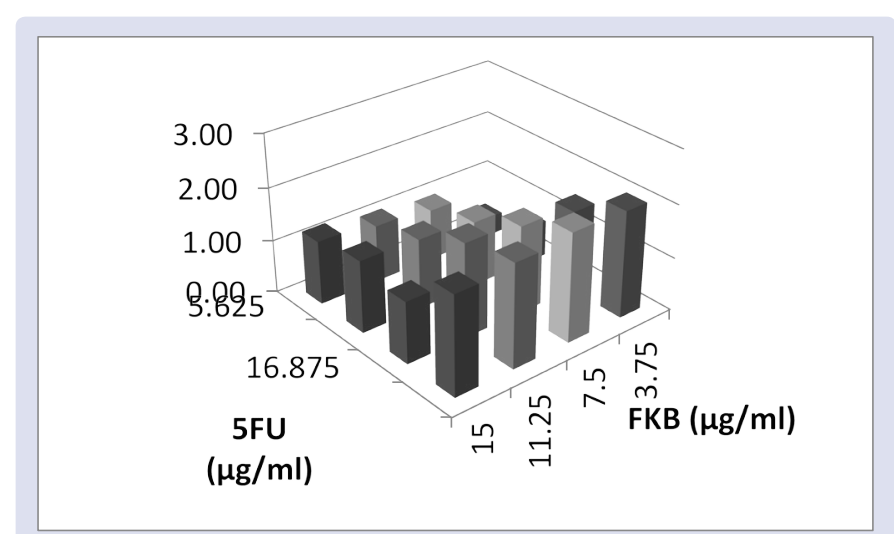

Figure 6. CFB and 5-FU Combined $\mathrm{Cl}$ score comparison curves. 


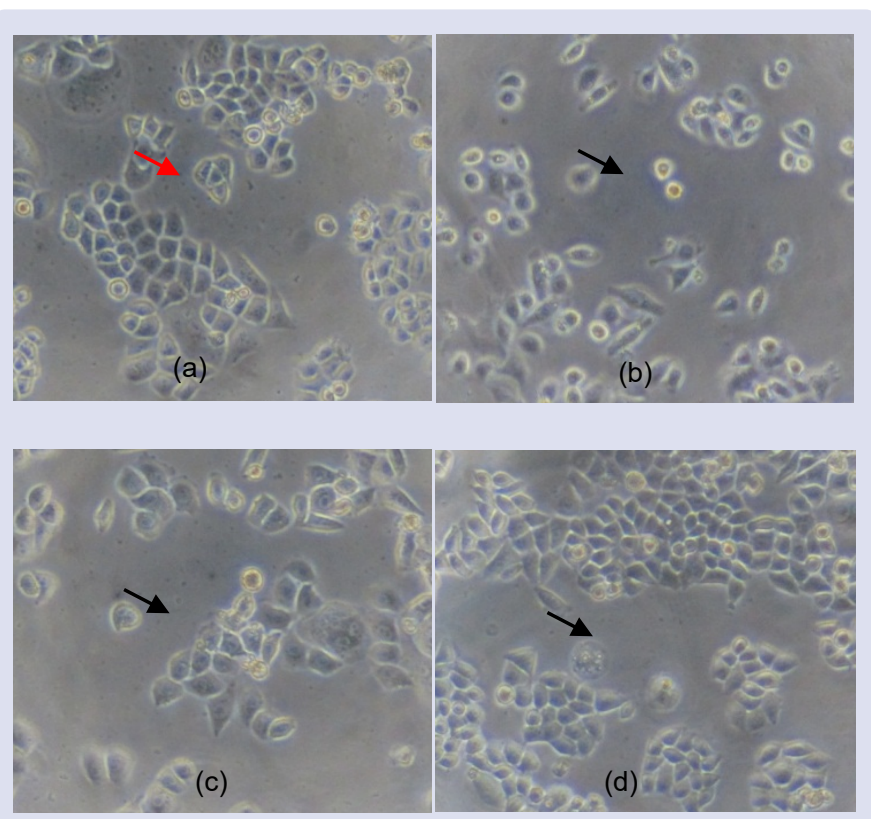

Figure 7. HeLa cell morphology representation under inverted microscope (3) at treatment (a) CFB $3.75 \mu \mathrm{g} / \mathrm{ml}$, (b) $5-\mathrm{FU} 5,625 \mu \mathrm{g} / \mathrm{ml}$, (c) Combination CFB $3.75 \mu \mathrm{g} / \mathrm{ml}$ and 5-FU 5,625 $\mu \mathrm{g} / \mathrm{ml}$, (d) cell control; Red arrow $(\rightarrow)$ show cells undergoing morphological changes; The black arrow $(\rightarrow)$ indicates a HeLa normal cell.

\section{CONCLUSION}

Chloroform fraction of Bandotan herb has strong potency to develop as co-chemoterapeutic agent with 5-FU in HeLa cervical cancer cells line based on in vitro and in silico assay.

Nobiletin as the active compound has high potency to develop as chemopreventive agents based on in silico assay.

\section{ACKNOWLEDGEMENT}

This research was funded by Hibah Kemitraan LP3M UMY grant 2017 from Universitas Muhammadiyah Yogyakarta.

\section{REFERENCES}

1. Anonymours. Cervical cancer: Estimated incidence, mortality and prevalence worldwide in 2012. http://globocan.iarc.fr/old/FactSheets/cancers/cervix-new. asp

2. Sudiana IK. Patobiologi Molekuler Kanker, Jakarta: Penerbit Salemba Medika. 2011.
3. Goodman A, Carmen MD, Chuang L. Cervical Cancer Screening in the Developing World and the Challenge of Caring for Woman with Cancer. J Womans Health Issue Care. 2014;3(1):1-2,

4. Lu JJ, Bao JL, Chen XP, Huang M, Wang YT. Alkaloid Isolated from Natural Herbs as the anticancer agent. J Evid Based Complementary Altern Med. 2012;1-12.

5. Kaur A, Kaur S. Anxiolytic Potential of Methanol Extract from Ageratum conyzoides Linn Leaves. Phcog J. 2015;7(4):236-41.

6. Larbie C, Torkornoo D, Dadson J. Anti-diabetic and hypolipidemic effect of botanical: A review of medicinal weeds on knust campus kumasi. J App Pharm Sci. 2014;4(10):97-104.

7. Puspitasari $\mathrm{H}$, Sukardiman, Widyawaruyanti. Study of cytotoxicity of methano extract of Ageratum conyzoides L. herbs against myeloma mice Cell. Pharmacy Magazine of Airlangga. 2003;3.

8. Hsiao PC, Lee WJ, Yang SF, Tan P, Chen HY, Lee LM, et al. Noboletin suppresses the proliferation and induces apoptosis involving MAPKs and caspase-8/-9/-3 signalsin human acute myeloid leukemia cells. Tumour Biol. 2014;35(12):1190311.

9. Tambunan AP, Bahtiar A, Tjandrawinata RR. Influence of extraction parameters on yield, phytochemical, TLC-densitometric quantification of quercetin and LCMS profile and how to standardize different batches for long term for Ageratum conyzoides L. leaves. Pharnacogn J. 2017;9(6):767-74

10. Mirunalini S, Maruthanila L, Isabella S. 3,3'-Diindolylmethane and 5-Fluorouraci act synergically to promote apoptosis and modify oxidant-antioxidant status on human cervical cancer (HeLa) cells. Eur J Pharm Med Res. 2017;4(1):612-7.

11. Sukardiman $R$, Studiawan $H$, Rahman A, Santosa MH, Pratama FA. Ethy acetate fraction of Andrographis Paniculata ness increases cytotoxic effect of 5-Fluorouracil on human cancer cell lines. Int J Pharm Sci. 2014;6(5):67-71.

12. Jemal A, Siegel R, Xu J, Ward E. Cancer statictics. CA Cancer J Clin. 2010;60(5):277-300.

13. Luo G, Guan X, Zhou L. Apoptotic effect of citrus fruit extract nobiletin on lung cancer cell line A549 In vitro And In vivo. Cancer Biol Ther. 2008;7(6):966-73.

14. Maiyanto E, Hermawan A, Junedi A, Fitriasari A, Susidarti RA. Nobiletin increased cytotoxic activity of doxorubicin on MCF-7 cells but not on T47D cell. Phytomedicine. 2011;3:129-37.

15. Korb O, Stutzle T, Exner TE. PLANTS: Application of ant colony optimation to structure-based drug design. Springer-Verlag Berlin Heidelberg. 2006.

16. Sanders CR. Biomolecular ligand-receptor binding studies: Theory, practice and analysis. http://structbio.vanderbilt.edu/sanders/Binding_Principles_2010.pdf.

17. Yoshimizu N, OtaniY, Sikawa T, KubotaT, Yoshida M, FurukawaT, et al. Anti-tumor effects of nobiletin, a citrus flavonoid, on gastric cancer include:antiproliferative effect, induction of apoptosis and cell cycle deregulation. Alments Pharmacol Ther. 2004;20(Suppl. 1):95-101.

18. Wang L, Wang J, Fang L, Zheng Z, Zhi D, Wang S, et al. Anticancer activities of citrus peel Polymethoxyflavones related to angiogenesis and others. Biomed Res Int. 2014;453972.

19. Li S, Pan MH, Wang Z, Lambros T, Ho CT. Biological activity, metabolism and separation of Plolymetoxyflavonoids from citrus peels. TFSB. 2008;2(1):36-51.

20. Huang H, Li L, Shi W, Liu H, Yang J, Yuan X, et al. The multifunctional effect of nobiletin and its metabolites in vivo and in vitro. J Evid Based Complementary Altern Med. 2016;2918796.

21. Chipuk JE, Moldoveanu T, Llambi F, Parsons MJ, Green DR. The Bcl-2 Family Reunion. Molecular Cell. 2010;37:299-310. 


\section{GRAPHICAL ABSTRACT}
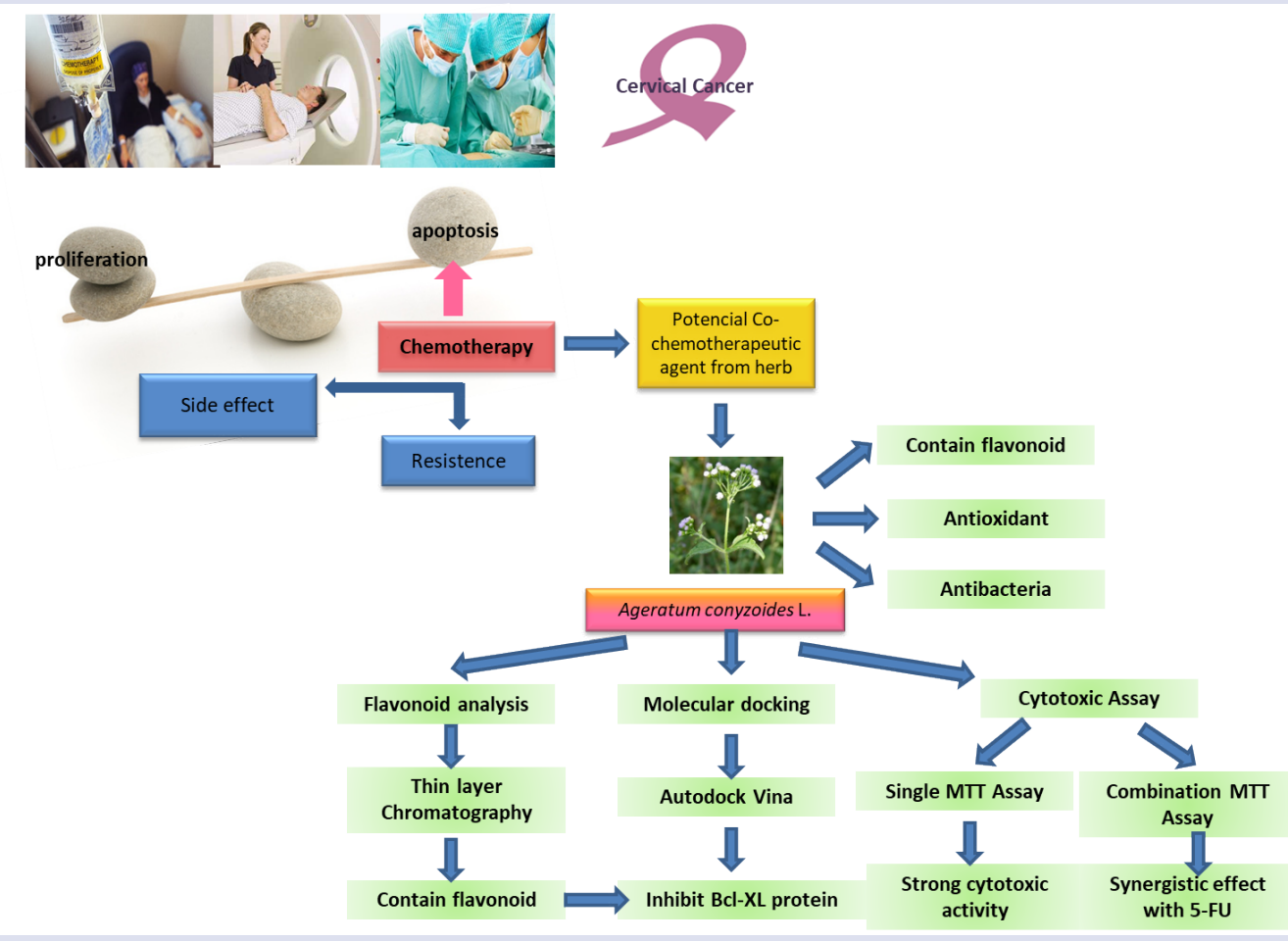

\section{ABOUT AUTHORS}

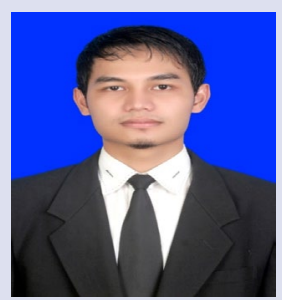

Rifki Febriansah was graduated for his undergraduate and master degree from Faculty of Pharmacy, Universitas Gadjah Mada Yogyakarta. Now he was still studying to pursue his doctoral degree in Faculty of Medicine, Universitas Gadjah Mada Yogyakarta. He is a lecturer and researcher in cell culture laboratory, school of Pharmacy, Faculty of Medicine and Health Sciences, Universitas Muhammadiyah Yogyakarta. His research projects are focus on Herbal medicine and tried to solve the mechanism of action of herbal medicine, especially for chemopreventive agent.

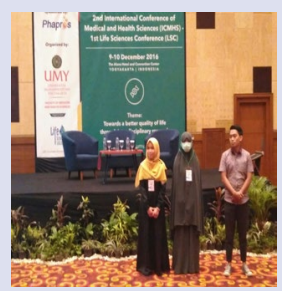

Titi Komalasari was graduated for her undergraduate from School of Pharmacy, Faculty of Medicine and Health Sciences, Universitas Muhammadiyah Yogyakarta. Her research projects are focus on Herbal medicine as chemopreventive agent.

Cite this article: Febriansah R, Komalasari T. Co-Chemotherapeutic Effect of Ageratum conyzoides L. Chloroform Fraction and 5-Fluorouracil on Hela Cell Line. Pharmacog J. 2019;11(5):913-8. 